\title{
Strategi Perencanaan dan Perancangan REDESAIN BALAI LATIHAN KERJA Kota SuRAKARTA
}

\author{
Bernadeta Fidela Putri, Hari Yuliarso, Ummul Mustaqimah \\ Program Studi Arsitektur \\ Fakultas Teknik \\ Universitas Sebelas Maret Surakarta \\ Email: bernadetafidela@gmail.com
}

\begin{abstract}
The working world demands to the skilled workers encourage the job seekers attending non-formal training and education to increase their skills and expertise. In this case the Ministry of Manpower and Transmigration through the Technical Managing Unit (UPT) Vocational Training Center (BLK) have important role in preparing the job training. Surakarta Vocational Training Center $(B L K)$ is one of the training center located in Surakarta city which serves as a training and education place for the job seekers in their productive age from the city. As a potential educational and training facilities that still work properly, this building still has problems in some aspects, therefore in an attempt to keep its function well, need a plan to redesign. The redesign will be consists of creating a space to cater all the activities in Surakarta Vocational Training Center and taking form fitting to introduce its existence to society. The redesign method is Post Occupancy Evaluation (POE) on the conditions and elements of the existing buiding, with the redesign strategy that emphasizes functional aspects, technical aspect such as building physical condition, and behavioural aspects to be solved in accordance with the concept of redesigning. This redesign method will be a reference in consideration of planning and design for the new building. The redesign of Vocational Training Center (BLK) in Surakarta city aims to improve the condition of the building and its surroundings in order to provide convenient education and training center.
\end{abstract}

Keywords: Post Occupancy Evaluation (POE), Redesign, Surakarta City, Vocational Training Center.

\section{PENDAHULUAN}

Balai Latihan Kerja merupakan tempat pendidikan dan pelatihan keterampilan kerja dalam rangka pembinaan Sumber Daya Manusia untuk mengasah kemampuan bekerja melalui pembelajaran pengetahuan dan keterampilan serta pelatihan yang akan menghasilkan tenaga kerja terampil dan profesional serta mampu menjawab permasalahan yang dihadapi oleh dunia industri akan kebutuhan tenaga kerja perusahaan yang terampil dan kompeten. Pelatihan kerja memiliki peran yang sangat penting dan strategis dalam peningkatan kualitas Sumber Daya Manusia karena sifat pelatihan kerja yang fleksibel dan dinamis dalam mengantisipasi kemajuan teknologi serta perubahan lingkungan dan persyaratan kerja yang berubah dengan cepat.
Kementerian Tenaga Kerja dan Transmigrasi berusaha mengoptimalkan fasilitas dan program-program pelatihan kerja yang tersedia di balai-balai latihan kerja (BLK) di seluruh Indonesia untuk mempercepat penyerapan tenaga kerja dan mengurangi angka pengangguran di pusat dan daerah. Kota Surakarta sebagai salah satu kota yang mulai berkembang memiliki sarana dan prasarana pelatihan keterampilan kerja yaitu di Balai Latihan Kerja Kota Surakarta. Balai Latihan Kerja yang ada di Kota Surakarta merupakan Balai Latihan Kerja Unit Pelaksana Teknis (UPT) yang berada di bawah naungan Kementerian Tenaga Kerja dan Transmigrasi dan bertanggung jawab pada Dinas Sosial Tenaga Kerja dan Transmigrasi (Dinsosnakertrans) Kota Surakarta. 
Balai Latihan Kerja Kota Surakarta mampu meluluskan 3312 orang per tahun (BLK Surakarta,2016) dari berbagai kejuruan pelatihan yang ada, jumlah ini tergolong besar dibandingkan dengan jumlah lulusan di BLK lainnya. Namun, sebagai wadah pendidikan dan pelatihan kerja yang masih beroperasional dengan cukup baik, Balai Latihan Kerja Kota Surakarta masih memiliki permasalahan, seperti adanya perubahan fungsi bangunan yang semula Balai Besar Latihan Kerja Industri Kota Surakarta menjadi Balai Latihan Kerja Kota Surakarta berpengaruh pada tata ruang dan prasarana, tidak adanya area parkir yang memadai, kelengkapan ruang yang belum optimal sesuai standar, dan masalah tampilan bangunan. Oleh karena itu, sebagai salah satu sarana dan prasarana pendidikan dan pelatihan kerja yang potensial dan masih aktif beroperasi, kelayakan dan kenyamanan suatu Balai Latihan Kerja perlu diperhatikan.

Dari permasalahan di atas, maka diperlukan adanya perencanaan dan perancangan kembali Balai Latihan Kerja Kota Surakarta yang dapat menampung seluruh kegiatan pendidikan dan pelatihan kerja dengan nyaman, berupaya mengenalkan Balai Latihan Kerja kepada masyarakat dan meningkatkan kualitas wadah pelatihan kerja yang ada di Kota Surakarta, serta mendayagunakan fungsi Balai Latihan Kerja untuk menghadapi jumlah pencari kerja di Kota Surakarta yang terus meningkat. Perencanaan dan perancangan yang dilakukan mencakup beberapa aspek perbaikan sesuai Post Occupancy Evaluation (POE) berdasarkan permasalahan yang ada di bangunan lama, yang meliputi aspek fungsi, aspek teknis, dan aspek perilaku. Redesain Balai Latihan Kerja Kota Surakarta ini merujuk pada berbagai upaya untuk memperbaiki kualitas Balai Latihan Kerja Kota Surakarta agar menjadi lingkungan pelatihan kerja yang memenuhi standar dan nyaman.

\section{METODE}

\subsection{Macam dan Teknik Pengumpulan Data}

1. Data Eksisting: data ini didapat melalui observasi dan dokumentasi ke bangunan lama Balai Latihan Kerja Kota Surakarta serta melalui situs dan artikel terkait.
2. Kondisi Eksisting Balai Latihan Kerja Kota Surakarta: data ini didapat melalui observasi, survey lapangan, dan wawancara dengan pihak Balai Latihan Kerja Kota Surakarta, kemudian dikaitkan dengan kajian teori dari buku perkuliahan.

3. Standar Balai Latihan Kerja: data standar didapat dari Peraturan Kementerian Tenaga Kerja dan Transmigrasi, Peraturan Menteri, selain itu juga dari studi literatur tentang bangunan.

\subsection{Metode Analisis Data}

Metode analisis data yang digunakan dalam Redesain Balai Latihan Kerja yaitu dengan Post Occupancy Evaluation (POE) atau Evaluasi Pasca Huni. Evaluasi Pasca Huni merupakan kegiatan peninjauan kembali (evaluasi) terhadap bangunan atau lingkungan yang binaan yang telah dihuni, tujuannya adalah menilai kinerja bangunan sudah sejalan dengan kriteria perancangannya dan mengatasi ketidaktepatan atau masalah pada fungsi, teknis, dan perilaku di dalam bangunan.

1. Faktor fungsional mengidentifikasi penggunaan Balai Latihan Kerja dan segala aspek yang secara langsung mendukung kegiatan yang ada di Balai Latihan Kerja, berpedoman pada kesesuaian antara area kegiatan dengan segala kegiatan yang berlangsung di dalamnya. Evaluasi ini akan berpengaruh pada fleksibilitas karena menjadi pertimbangan rancangan tata ruang dan prasarana.

2. Faktor teknis menjelaskan lingkungan latar belakang bangunan, kondisi fisik bangunan Balai Latihan Kerja dan teknis ruang.

3. Faktor perilaku menghubungkan faktorfaktor lingkungan fisik Balai Latihan Kerja yang berpengaruh terhadap kegiatan pengguna bangunan dan faktor psikologis, permasalahan perilaku yang diperhatikan seperti teritori, privasi dan interaksi, persepsi, citra dan makna.

\section{ANALISIS}

\subsection{Analisis Peruangan}

Analisis kebutuhan ruang diperoleh dari analisis identifikasi pelaku dan pola kegiatan pelaku pada kondisi eksisting Balai Latihan Kerja Kota Surakarta sehingga seluruh 
kegiatan dapat terwadahi. Berikut ini adalah pelaku di Balai Latihan Kerja:

1. Peserta didik pelatihan (utama)

2. Instruktur dan pengelola

3. Pengunjung umum

Berdasarkan hasil analisis pelaku dan pola kegiatan pelaku di Balai Latihan Kerja maka kegiatan yang diwadahi dapat dikelompokkan menjadi beberapa kelompok kegiatan. Ruang yang dibutuhkan harus mampu mewadahi semua kegiatan utama yaitu pelatihan kerja. Selain itu, diperlukan ruang untuk pengelola, pendukung, dan servis. Berikut kelompok kebutuhan ruang pada Balai Latihan Kerja yang direncanakan:

Tabel 1. Kebutuhan Ruang

\begin{tabular}{|c|c|}
\hline $\begin{array}{l}\text { Kelompok } \\
\text { Kegiatan }\end{array}$ & Kebutuhan Ruang \\
\hline $\begin{array}{l}\text { Kegiatan } \\
\text { Penerimaan }\end{array}$ & $\begin{array}{l}\text { - Lobby } \\
\text { - Ruang tamu } \\
\text { - Ruang informasi } \\
\text { dan pendaftaran }\end{array}$ \\
\hline $\begin{array}{l}\text { Kegiatan } \\
\text { Pelatihan } \\
\text { Kerja }\end{array}$ & $\begin{array}{l}\text { - Ruang kelas teori } \\
\text { tiap kejuruan } \\
\text { - Ruang workshop } \\
\text { tiap kejuruan }\end{array}$ \\
\hline $\begin{array}{l}\text { Kegiatan } \\
\text { Pengelola } \\
\end{array}$ & $\begin{array}{l}\text { - Ruang kantor } \\
\text { pengelola }\end{array}$ \\
\hline $\begin{array}{l}\text { Kegiatan } \\
\text { Pendukung }\end{array}$ & $\begin{array}{l}\text { - Ruang rapat } \\
\text { - Ruang diskusi } \\
\text { - Ruang seminar } \\
\text { - Perpustakaan } \\
\text { - Guest house } \\
\text { - Kantin } \\
\text { - Toilet } \\
\text { - Parkir } \\
\text { - Halaman }\end{array}$ \\
\hline $\begin{array}{l}\text { Kegiatan } \\
\text { Servis }\end{array}$ & $\begin{array}{l}\text { - Pantry } \\
\text { - Ruang genset } \\
\text { - Ruang ME } \\
\text { - Ruang panel }\end{array}$ \\
\hline
\end{tabular}

\subsection{Analisis Eksisting Lokasi}

Lokasi perencanaan terletak pada lahan bangunan lama dengan mengoptimalkan potensi yang ada. Berikut ini adalah lokasi tapak Balai Latihan Kerja:

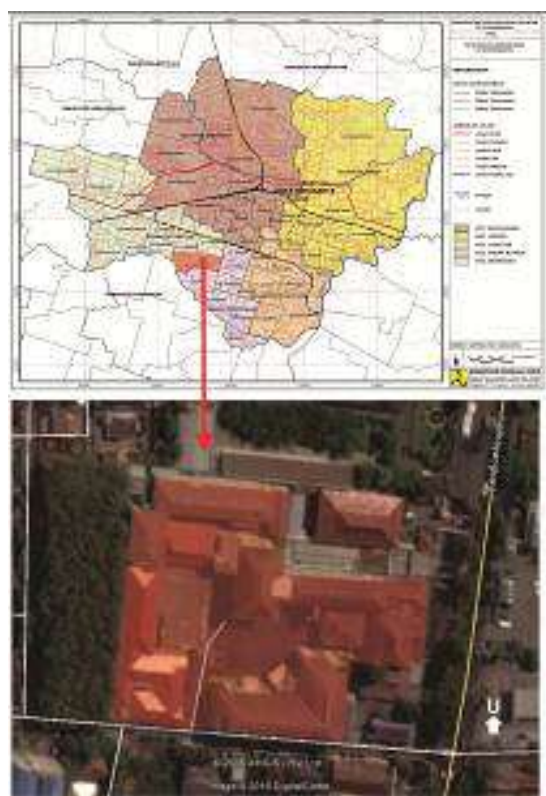

Gambar 1. Lokasi Tapak

Lokasi eksisting cukup strategis, berada di tengah Kota Surakarta dan dilalui Jalan Bhayangkara sebagai jalan arteri kota. Batasbatas tapak:

Utara : Bimbel Ganesha Operation

Selatan : Jalan lingkungan dan bangunan cuci mobil

Timur : Jalan Bhayangkara

Barat : Lahan kosong

\subsection{Analisis Pencapaian}

Pencapaian ke dalam bangunan harus mudah diakses, mudah dilihat dan memiliki sirkulasi yang aman.

\subsubsection{Tujuan}

Menentukan main entrance dan side entrance.

\subsubsection{Dasar Pertimbangan}

1. Kemudahan akses

2. Arus lalu lintas kendaraan dan potensi jalan

3. Tingkat keamanan

\subsubsection{Proses Analisis}

Main entrance diakses langsung dari Jalan Bhayangkara sebagai jalan utama, serta berkaitan dengan kemudahan akses dan sarana transportasi.

Side entrance diakses langsung dari jalan lingkungan sebagai satu-satunya jalan selain jalan utama. Akses ini dimanfaatkan apabila terjadi sirkulasi yang padat di main entrance. 


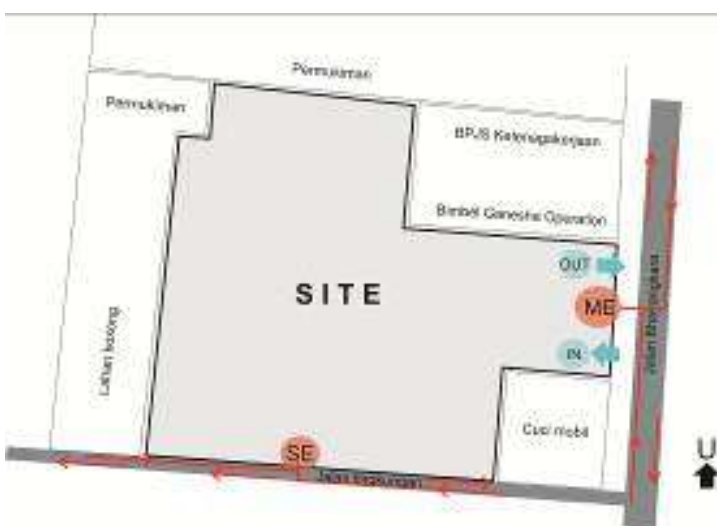

Gambar 2. Letak ME dan SE

\subsection{Analisis Klimatologis}

Analisis klimatologis dilakukan untuk menentukan respon bangunan Balai Latihan Kerja Kota Surakarta yang direncanakan terhadap iklim khususnya sinar matahari, angin, dan hujan. Berdasarkan analisis yang dilakukan, berikut adalah hasil respon desain yang diterapkan pada bangunan:

1. Penggunaan elemen sun shading iklim berupa secondary skin yang berfungsi melindungi fisik bangunan dari terpaan cuaca, baik matahari maupun hujan. Karena terdapat banyak jendela, maka penerapan secondary skin pada sisi bangunan Balai Latihan Kerja Kota Surakarta dapat meminimalkan efek panas sinar matahari yang masuk ke dalam ruang. Selain mengedepankan fungsinya, secondary skin juga dapat menambah estetika fasad bangunan.

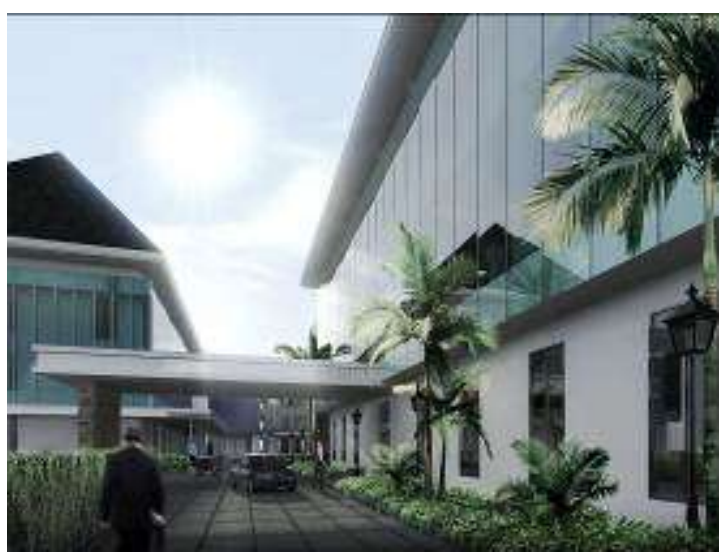

Gambar 3. Elemen Secondary Skin

2. Penataan vegetasi sebagai penahan panas dan elemen penyejuk di lingkungan Balai Latihan Kerja Kota Surakarta.

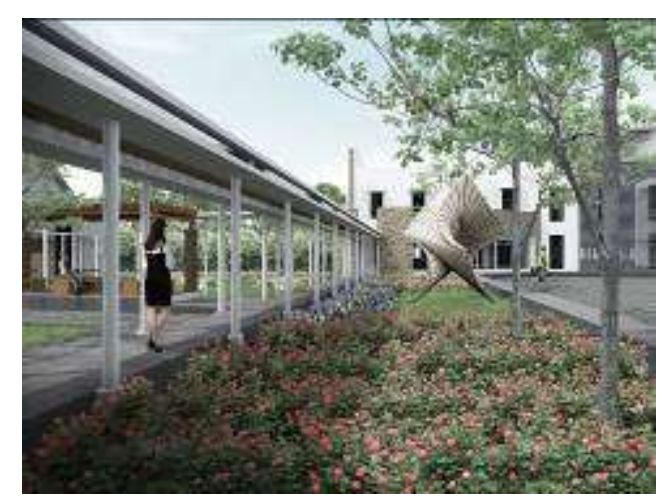

Gambar 4. Ruang Terbuka (Taman)

\subsection{Analisis Pemintakatan}

Pemintakatan berdasarkan jenis kegiatan yang saling berhubungan untuk mempermudah pelaku kegiatan mengakses setiap bagian bangunan. Penentukan mintakat berdasarkan analisis jenis kegiatan, kelompok ruang dan persyaratan ruang di Balai Latihan Kerja Kota Surakarta. Selain itu, analisis pemintakatan mempertimbangkan keterkaitan hubungan antar kelompok kegiatan dan karakter bentuk tapak.

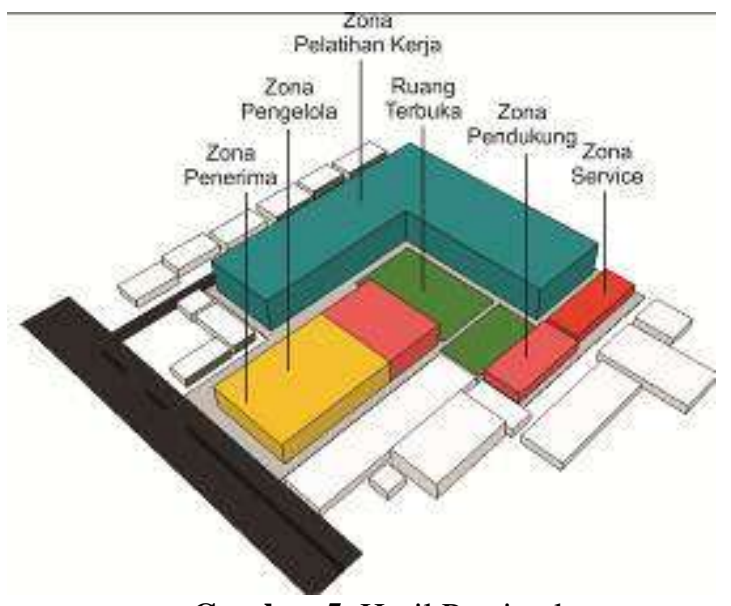

Gambar 5. Hasil Pemintakatan

\subsection{Analisis Bentuk dan Tampilan Bangunan}

\subsubsection{Analisis Bentuk Bangunan}

\subsubsection{Tujuan}

Memperoleh layout bentuk bangunan yang sesuai dengan fungsi dan jenis kegiatan yang diwadahi di Balai Latihan Kerja.

\subsubsection{Dasar Pertimbangan}

1. Karakter kegiatan

2. Bentuk eksisting tapak

3. Orientasi dan kemudahan pencapaian bangunan 
4. Kenyamanan pengguna

\subsubsection{Proses Analisis}

Massa bangunan yang diterapkan berupa massa majemuk, yaitu terdiri atas beberapa massa yang dibagi berdasarkan fungsi kegiatan berbeda. Massa utama adalah massa yang mewadahi kegiatan utama yaitu pelatihan kerja teori dan workshop, sedangkan lainnya adalah massa bangunan pengelola dan massa bangunan pendukung. Massa mengalami vertikalisasi hingga 2 lantai untuk bangunan pengelola, dan 3 lantai untuk bangunan utama workshop. Massa bangunan ditata dengan pola mengikuti bentuk karakter tapak yang terbatas di bagian timur namun melebar di bagian barat menjadikan bentuk tapak memanjang ke dalam sehingga pola yang diaplikasikan adalah pola yang berorientasi ke arah tengah. Orientasi bangunan massa bangunan kelas, workshop, dan pendukung menghadap ke arah dalam, sedangkan orientasi bangunan kantor pengelola memiliki orientasi ganda yaitu ke arah dalam dan luar tapak.

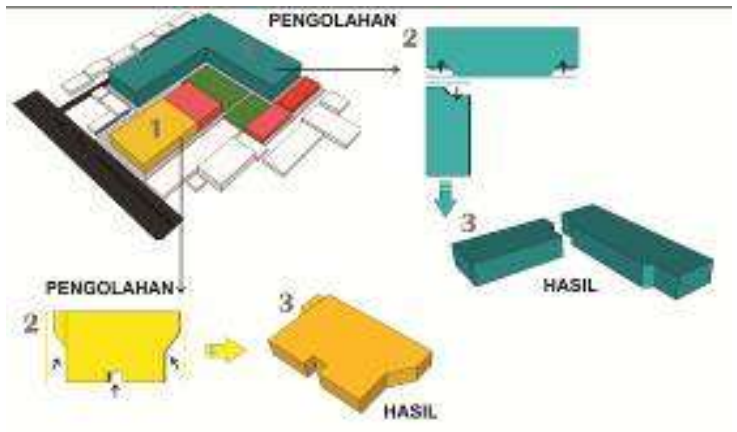

Gambar 6. Gubahan Bentuk Massa

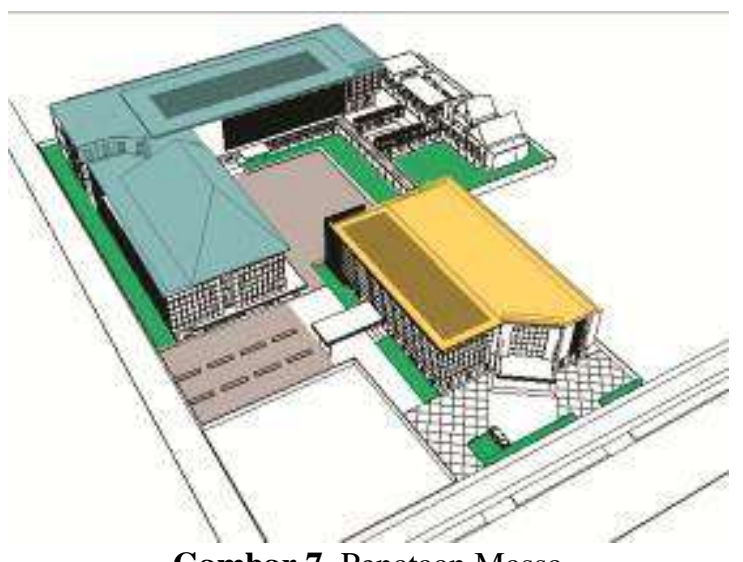

Gambar 7. Penataan Massa

3.6.2 Analisis Tampilan Bangunan

3.6.2.1 Tujuan
Mendapatkan tampilan Balai Latihan Kerja yang baru.

\subsubsection{Dasar Pertimbangan}

1. Tampilan bangunan mampu menampilkan karakter bangunan Balai Latihan Kerja sesuai dengan kegiatan yang diwadahi.

2. Penyegaran tampilan yang berbeda dari bangunan lama.

\subsubsection{Proses Analisis}

Tampilan bangunan menerapkan konsep bangunan modern dengan pengolahan geometris agar lebih dinamis, penggunaan elemen secondary skin dari beberapa material seperti kaca, kisi-kisi besi, dan kayu, yang berfungsi selain untuk merespon iklim, juga menambah estetika tampilan keseluruhan bangunan.
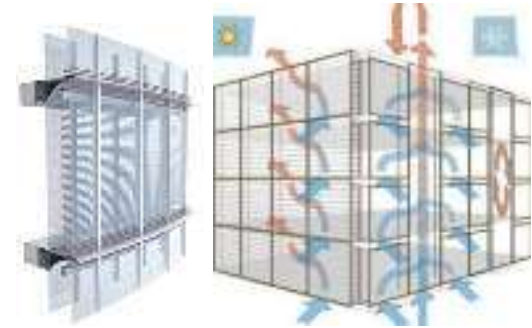

Gambar 8. Secondary Skin Facade (pinterest.com)

Fasade bangunan juga diolah dengan finishing dinding Aluminium Composite Panel (ACP). Kemudian alternatif warna yang digunakan pada fasade adalah warna-warna netral.

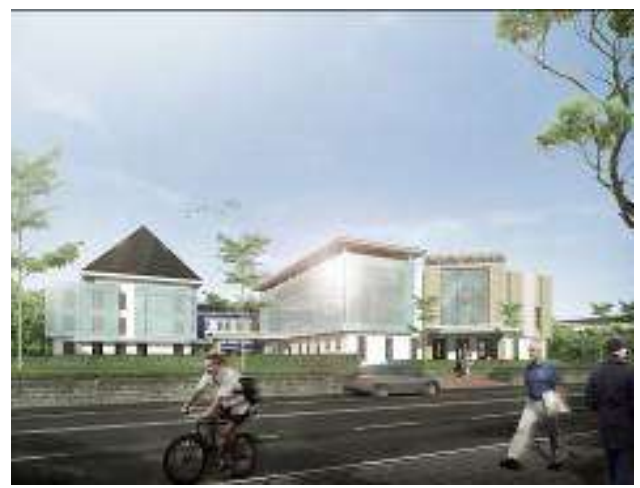

Gambar 9. Penerapan Tampilan Bangunan Modern 


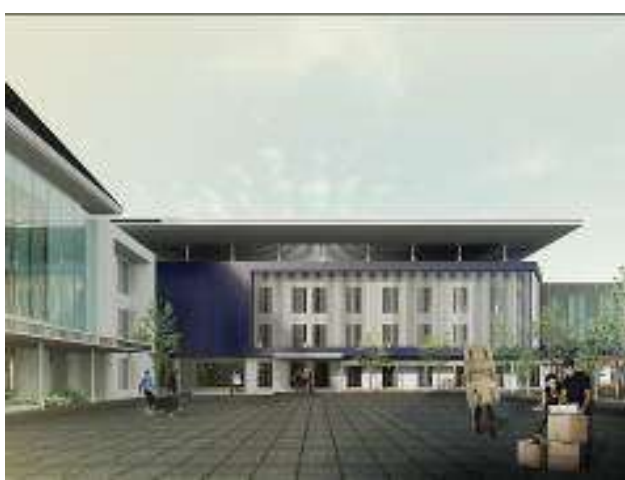

Gambar 10. Tampilan Bangunan Workshop

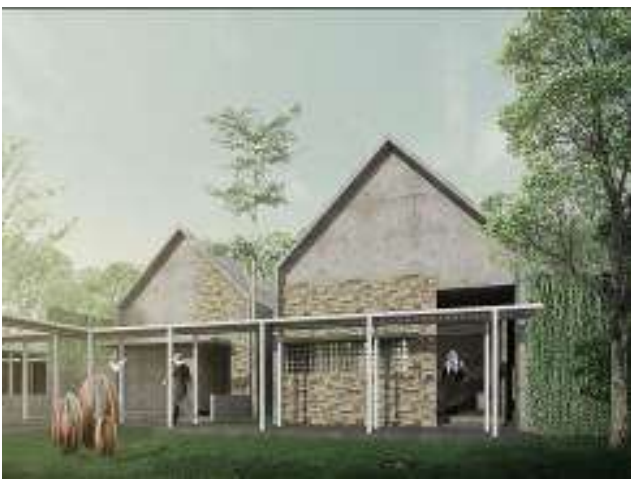

Gambar 11. Tampilan Bangunan Penunjang

\subsection{Analisis Struktur}

\subsubsection{Tujuan}

Menentukan sistem struktur yang tepat untuk bangunan dua hingga tiga lantai sehingga mampu menunjang kegiatan yang diwadahi.

\subsubsection{Dasar Pertimbangan}

1. Bentuk dasar massa berupa persegi

2. Tampilan bangunan Balai Latihan Kerja baru

Sistem struktur pada bangunan terbagi menjadi berikut ini:

\section{Upper Structure}

Sesuai dengan pertimbangan dan dalam upaya penyegaran tampilan bangunan yang berbeda dari bangunan lama, maka pemilihan sistem upper structure adalah berupa atap dak beton. Selain itu, struktur rangka baja juga digunakan untuk menopang penggunaan atap limasan sebagai unsur lokalitas. Pada atap dak beton terdapat penambahan elemen atap Aluminium Composite Panel (ACP) sebagai aksen arsitektural.

2. Super Structure
Sistem yang digunakan adalah sistem kolom dan balok sebagai rangka ruang sekaligus sebagai penyalur beban bangunan menuju pondasi. Sistem ini lebih mudah diterapkan ke bentuk massa bangunan Balai Latihan Kerja dan sesuai dengan tuntutan kebutuhan efisiensi pembagian ruang-ruang di Balai Latihan Kerja.

\section{Sub Structure}

Sistem sub struktur yang sesuai untuk bangunan Balai Latihan Kerja Kota Surakarta adalah sistem pondasi footplate yang mampu menyalurkan beban ke tanah dan umum digunakan untuk bangunan dua hingga tiga lantai.

\subsection{Analisis Utilitas}

\subsubsection{Pencahayaan}

Balai Latihan Kerja Kota Surakarta merencanakan penggunaan pencahayaan alami yang optimal terutama pada ruang-ruang workshop serta menerapkan bukaan-bukaan ruang yang efisien.

\subsubsection{Penghawaan}

Penghawaan alami melalui perencanaan bukaan yang dapat meneruskan laju angin.

\subsubsection{Sistem Sanitasi}

1. Sumber air bersih berasal dari PDAM dan sumur dengan sistem tangki atap, dialirkan melalui shaft pada bangunan lalu didistribusikan ke bagian-bagian bangunan.

2. Sistem pembuangan air kotor disposal cair (black water dan grey water) disalurkan ke septictank lalu ke sumur resapan dan dibuang ke riol kota. Pembuangan disposal padat (sampah) dikelola oleh petugas tertentu.

3. Pembuangan air hujan pada atap dak beton dialirkan melalui melalui talang air dan pipa plumbing yang kemudian diresapkan atau dibuang ke riol kota.

\section{KESIMPULAN (KONSEP DESAIN)}

Konsep rancangan redesain Balai Latihan Kerja merespon dan bertujuan mengatasi permasalahan yang ada di bangunan eksisting serta berupaya dalam peningkatan kualitas bangunan dari aspek fungsi, aspek teknis, dan aspek perilaku. Dengan adanya rancangan 
redesain ini maka diharapkan Balai Latihan Kerja Kota Surakarta dapat menjadi tempat pelatihan keterampilan kerja yang nyaman dan berkarakter.

Dari hasil analisis serta hasil korelasi dari beberapa data di atas, maka diperoleh hasil berupa konsep rancangan Redesain Balai Latihan Kerja Kota Surakarta sebagai berikut:

Tabel 2. Konsep Desain

\begin{tabular}{|c|c|}
\hline Pendekatan & Hasil \\
\hline Fisik Lingkungan & 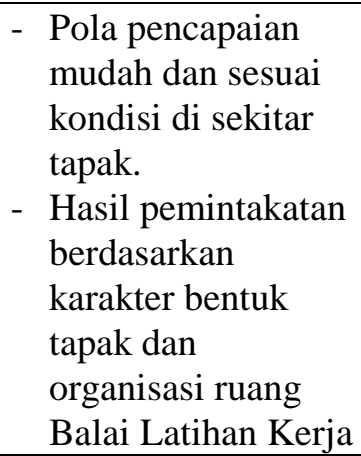 \\
\hline Ruang & $\begin{array}{l}\text { - Program ruang } \\
\text { yang sesuai dengan } \\
\text { kebutuhan kegiatan } \\
\text { yang diwadahi } \\
\text { - Ruang-ruang } \\
\text { workshop yang } \\
\text { sesuai standar } \\
\end{array}$ \\
\hline Iklim & $\begin{array}{l}\text { Memanfaatkan } \\
\text { potensi iklim untuk } \\
\text { menunjang } \\
\text { kenyamanan ruang } \\
\text { melalui respon } \\
\text { desain yang sesuai } \\
\end{array}$ \\
\hline Arsitektural bangunan & $\begin{array}{l}\text { - } \text { Bentuk massa } \\
\text { menyesuaikan } \\
\text { kondisi karakter } \\
\text { eksisting tapak } \\
\text { - } \text { Tampilan } \\
\text { bangunan modern } \\
\text { dengan tujuan } \\
\text { penyegaran } \\
\text { tampilan yang } \\
\text { berbeda dari } \\
\text { bangunan BLK } \\
\text { lama }\end{array}$ \\
\hline
\end{tabular}

\section{REFERENSI}

Danisworo, Muhammad. 1989. Post Occupancy Evaluation, Pengertian dan
Metodologi. Jakarta: Universitas Trisakti.

Departemen Tenaga Kerja dan Transmigrasi. Standar Minimum BLK, https://www.scribd.com/doc/61175903/ Standar-Minimal-Blk (diakses pada tanggal 12 Mei 2016)

Snyder, James C. dan Anthony J. Catanese. 1985. Pengantar Arsitektur. Jakarta: Penerbit Erlangga 